\title{
Regulated expression of two sets of paternally imprinted genes is necessary for mouse parthenogenetic development to term
}

\author{
Qiong Wu, Takuya Kumagai, Manabu Kawahara, Hidehiko Ogawa, Hitoshi Hiura, \\ Yayoi Obata, Riya Takano and Tomohiro Kono \\ Department of BioScience, Tokyo University of Agriculture, Setagaya-ku, Tokyo 156-8502, Japan \\ Correspondence should be addressed to T Kono; Email: tomohiro@nodai.ac.jp
}

\begin{abstract}
Mouse parthenogenetic embryos (PEs) are developmentally arrested until embryo day (E) 9.5 because of genomic imprinting. However, we have shown that embryos containing genomes from non-growing (ng) and fully grown (fg) oocytes, i.e. $\mathrm{ng}^{\mathrm{wt}} / \mathrm{fg}^{\mathrm{wt}}$ PE (wt, wild type), developed to E13.5. Moreover, parthenogenetic development could be extended to term by further regulation of Igf2 and $H 19$ expression using mice with deletion of the $H 19$ transcription unit (H19s13) together with its differentially unit (DMR). To gain an insight into the extended development of the parthenotes to term, we have here investigated the expression levels of paternally imprinted genes in $\mathrm{ng}^{\mathrm{H} 19 \Delta 13} / \mathrm{fg}^{\text {wt }} \mathrm{PE}$ throughout their development. In $\mathrm{ng}^{\mathrm{H} 19 \Delta 13} / \mathrm{fg}^{\mathrm{wt}}$ Pes that died soon after recovery, the expression of Igf2 and $\mathrm{H} 19$ was restored to the appropriate levels except for low Igf2 expression in the liver after E15.5. Further, the paternally expressed Dlk1 and Dio3 were repressed, while the expression levels of the maternal Gt/2 and Mirg were twice those of the controls. However, the above-mentioned four genes showed almost normal expression in the surviving $\mathrm{ng}^{\mathrm{H} 19 \Delta 13} / \mathrm{fg}^{\text {wt }} \mathrm{PEs}$. The methylation analysis revealed that the intragenic DMR of the Dlk1-Gt/2 domain was hypermethylated in the $\mathrm{ng}^{\mathrm{H} 19 \Delta 13} / \mathrm{fg}^{\mathrm{wt}} \mathrm{PEs}$ that survived, but not in the PEs that died soon after recovery. The present study suggests that two sets of co-ordinately regulated but oppositely expressed genes, Igf2-H19 and DIk1-Gt/2, act as a critical barrier to parthenogenetic development in order to render a paternal contribution obligatory for descendants in mammals.
\end{abstract}

Reproduction (2006) 131 481-488

\section{Introduction}

Parental genomes are required for both complete normal development and postnatal growth for genomic imprinting in mammals; this leads to the differential expression of genes between maternal and paternal alleles. Genomic imprinting acts as a strict barrier for parthenogenetic development; this is evident from results showing that parthenogenetic embryos could never develop beyond embryo day (E) 10 in mice (Surani \& Barton 1983). To establish the parental-specific gene expression, certain loci of imprinted genes are differentially modified at some point either during spermatogenesis or oogenesis. In females, maternal-specific modifications are imposed during oocyte growth (Kono et al. 1996, Obata \& Kono 2002); therefore, non-growing (ng) oocytes remain naïve at imprinting. A previous study by our group (Kono et al. 1996) demonstrated that an oocyte containing two haploid sets of genomes from ng and fully grown (fg) oocytes developed to E13.5 (ng ${ }^{\mathrm{wt}} / \mathrm{fg}^{\mathrm{wt}}$ PE) (wt; wild type). Gene expression analysis showed that such types of parthenotes were accompanied by the appropriate expression of maternally imprinted genes, which were epigenetically modified during oocyte growth.

To address the question of whether the collective expression of lgf2 accompanied by $\mathrm{H} 19$ would result in the extended development of parthenotes, we used mice with deletion of the $H 19$ transcription unit $(\mathrm{H} 19 \Delta 13)$ together with its differentially methylated region (DMR) (Leighton et al. 1995) as an ng oocyte donor for the reconstruction of parthenogenetic embryos. In such types of parthenotes (ng ${ }^{\mathrm{H} 19 \Delta 13} / \mathrm{fg}^{\text {wt }} \mathrm{PE}$ ), the Igf2 and $\mathrm{H} 19$ genes were expressed and repressed respectively from the $\mathrm{ng}^{\mathrm{H} 19 \Delta 13}$ alleles. These embryos successfully developed to term (Kono et al. 2004). With the exception of two pups, all parthenogenetic pups showed severe growth retardation and died before or shortly after their recovery from the uterus at 19.5 days of gestation. Two sets of co-ordinately regulated but oppositely expressed genes - Igf2 and H19 and Dlk1 and Gt/2 (Kobayashi et al. 2000, Schmidt et al. 2000) - were located on chromosome 7 and chromosome 12 respectively, and 
both sets were paternally imprinted during spermatogenesis. The Igf2 and Dlk1 genes that were expressed from paternal alleles acted as a foetal growth factor (Feil et al. 1994, Leighton et al. 1995, Georgiades et al. 2000, Moon et al. 2002). The role of $H 19$ and Gt/2 genes, which are maternally expressed non-coding RNAs, is not completely known. The reason for the survival of only two parthenotes, and not the others, remains to be clarified. To gain further insight into the extended development of the $\mathrm{ng}^{\mathrm{H} 19 \Delta 13} / \mathrm{fg}^{\mathrm{wt}}$ parthenogenetic embryo (PE), we carried out quantitative expression analysis of another set of paternally imprinted genes (DIk1, Gt/2, Mirg and Dio3), which are members of the $1-\mathrm{Mb}$ imprinted cluster on distal chromosome 12 (Lin et al. 2003).

\section{Materials and Methods}

\section{Production of PEs}

Serial nuclear transfer was conducted to reconstruct oocytes of the two classes of PE (Kono et al. 1996). The genome types of these two classes are shown in Fig. 1. The fusion of the diplotene oocytes with enucleated germinal vesicle (GV) oocytes was induced by an inactivated Sendai virus. The reconstituted oocytes were then cultured for $14 \mathrm{~h}$ in $\alpha$-minimum essential medium ( $\alpha$-MEM) (GIBCOBRL, Grand Island, NY, USA). Throughout the experiment, the GV oocytes were manipulated in a medium containing $200 \mathrm{mM}$ dbcAMP and $5 \%$ calf serum and released from the medium $1 \mathrm{~h}$ after fusion with an $\mathrm{ng}$ oocyte. A set of MII (metaphase of the second meiotic division) chromosomes from the reconstituted oocytes was transferred into a freshly ovulated MII oocyte. These reconstructed oocytes were then artificially activated with $10 \mathrm{mMSrCl}_{2}$ in $\mathrm{Ca}^{2+}$-free M16 medium (Whittingham 1971) for $2 \mathrm{~h}$. These embryos were cultured in M16 medium for 3.5 days in an atmosphere of $5 \% \mathrm{CO}_{2}, 5 \% \mathrm{O}_{2}$ and $90 \% \mathrm{~N}_{2}$ at $37^{\circ} \mathrm{C}$. Blastocysts that were obtained from the constructed oocytes were transferred into the uterine horns of CD-1 female mice at day 2.5 of pseudopregnancy.

\section{Quantitative gene expression analysis}

Total RNAs were extracted from the major organs of the $\mathrm{ng}^{\mathrm{H} 19 \Delta 13} / \mathrm{fg}^{\mathrm{wt}}$ PEs, the $\mathrm{ng}^{\mathrm{H} 19 \Delta 13} / \mathrm{fg}^{\mathrm{wt}}$ PE survivors and controls at E12.5, 15.5, 18.5 and 19.5 by using an RNeasy mini kit (Qiagen, Tokyo, Japan). The cDNAs were synthesized using a SuperScript $\mathrm{RnaseH}^{\prime}$ reverse transcriptase kit (Invitrogen, Carlsbad, CA, USA) in a reaction solution $(20 \mu \mathrm{l})$ containing total RNA $(1 \mu \mathrm{g})$ prepared from the tissues. Next, this synthesized cDNA was used for the quantitative analysis of the expression of imprinted genes by means of real-time quantitative RT-PCR (LightCycler System; Roche Molecular Biochemicals, Mannheim, Germany) using a ready-to-use reaction mixture kit (LightCycler FirstStart DNA Master SYBR Green I; Roche Molecular Biochemicals). The primer sequences used for the PCR reaction, the PCR conditions and the product sizes are listed in Table 1. The Gapdh gene was used as a loading control.

\section{DNA preparation and bisulphite modification}

DNA was isolated from the tongue $(n=3)$ and intestine $(n=1)$ of the $\mathrm{ng}^{\mathrm{H} 19 \Delta 13} / \mathrm{fg}^{\mathrm{wt}} \mathrm{PE}$ with growth retardation at E18.5, and the intestine $(n=1)$ and tail $(n=1)$ of the $\mathrm{ng}^{\mathrm{H} 19 \Delta 13} / \mathrm{fg}^{\mathrm{wt}} \mathrm{PE}$ that survived (survivors) at 19.5 and adult Kaguya respectively (Kono et al. 2004). As a control, tongue and tail at E18.5 $(n=3)$ and adult tail $(n=1)$ were collected from wt and used for DNA preparation. Methylation analysis was carried out by subjecting the samples to bisulphite modification, PCR amplification, subcloning and sequencing for the intergenic germline-derived (IG)-DMR of Dlk1-Gt/2 (Takada et al. 2002). The isolated DNA was treated with sodium bisulphite using a CpGenome modification kit (CHEMICON, CA, USA).

\section{Staining (cartilage and bone)}

Embryos at E18.5 were eviscerated and fixed in 90\% ethanol for 2 weeks. Cartilage samples were stained with $0.01 \%$ Alcian blue (Sigma) in $80 \%$ ethanol and $20 \%$ glacial acetic acid. They were then rehydrated with a series of $70 \%, 40 \%$ and $15 \%$ ethanol incubations for $2 \mathrm{~h}$ with each concentration. For bone staining, samples were incubated with $0.001 \%$ Alizarin red (Sigma) in $1 \% \mathrm{KOH}$ for $2-5$ days. The samples were rinsed several times with $1 \%$ $\mathrm{KOH}$ and stored in glycerol.

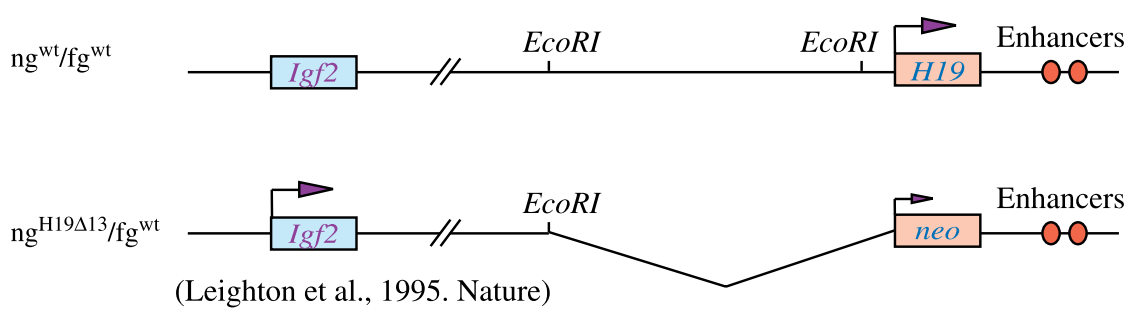

Figure 1 H19 genotypes of $\mathrm{ng}^{\mathrm{wt}} / \mathrm{fg}^{\mathrm{wt}}$ and $\mathrm{ng}^{\mathrm{H} 19 \Delta 13} / \mathrm{fg}^{\mathrm{wt}}$ PE. Only ng alleles are shown. Reproduced with permission form Leighton et al. (1995). 
Table 1 Real-time RT-PCR conditions for Gapdh and imprinted genes.

\begin{tabular}{|c|c|c|c|c|}
\hline Genes & Primer & $\mathrm{MgCl}_{2}$ & Annealing temp. & Product size \\
\hline H19 & 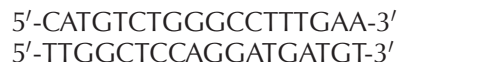 & $4 \mathrm{nM}$ & $55^{\circ} \mathrm{C}$ & $245 \mathrm{bp}$ \\
\hline $\operatorname{lgf} 2$ & $\begin{array}{l}\text { 5'-AGGGGAGCTTGTTGACACG-3' } \\
5^{\prime} \text {-GGGTATCTGGGGAAGTCGTC-3' }\end{array}$ & $2 \mathrm{mM}$ & $59^{\circ} \mathrm{C}$ & $225 \mathrm{bp}$ \\
\hline$G t / 2$ & $\begin{array}{l}5^{\prime} \text {-AAGCACCATGAGCCACTAGG-3' } \\
5^{\prime} \text {-TTGCACATTTCCTGTGGGAC-3 }\end{array}$ & $3 \mathrm{mM}$ & $62{ }^{\circ} \mathrm{C}$ & $288 \mathrm{bp}$ \\
\hline Dlkl & $\begin{array}{l}\text { 5'-ACTTGCGTGGACCTGGAGAA-3' } \\
5^{\prime} \text {-CTGTTGGTTGCGGCTACGAT-3' }\end{array}$ & $2 \mathrm{mM}$ & $62{ }^{\circ} \mathrm{C}$ & $221 \mathrm{bp}$ \\
\hline Mirg & $\begin{array}{l}5^{\prime} \text {-CCTTCCTGGATCTCTCGCTT-3' } \\
5^{\prime} \text {-GTGGGAGTTGAAACATGGGT-3' }\end{array}$ & $2 \mathrm{mM}$ & $62{ }^{\circ} \mathrm{C}$ & 162 bp \\
\hline Dio3 & $\begin{array}{l}\text { 5'-TGTACCTGACCACCGTTCA-3' } \\
5^{\prime} \text {-GGTGCACCTTGTTGTAGTACTC-3' }\end{array}$ & $4 \mathrm{nM}$ & $60^{\circ} \mathrm{C}$ & 209 bp \\
\hline Rasgrf1 & $\begin{array}{l}5^{\prime} \text {-ACCCAGGACTTTGATACCGA-3' } \\
5^{\prime} \text {-GTGTGAAGACTGAGCCCTTC-3' }\end{array}$ & $2 \mathrm{mM}$ & $57^{\circ} \mathrm{C}$ & 207 bp \\
\hline Gapdh & $\begin{array}{l}\text { 5'-GTCGTGGAGTCTACTGGTGTC-3' } \\
5^{\prime} \text {-GAGCCCTTCCACAATGCCAAA-3' }\end{array}$ & $2 \mathrm{mM}$ & $60^{\circ} \mathrm{C}$ & $240 \mathrm{bp}$ \\
\hline
\end{tabular}

\section{Statistical analysis}

The data regarding the rate of development of the embryos were analyzed by Chi-square analysis (a $P$ value of less than 0.01 was considered to be statistically significant).

\section{Results}

\section{In vivo growth of the PES}

In order to obtain the foetal growth curve of the $\mathrm{ng}^{\mathrm{H} 19 \Delta 13} / \mathrm{fg}^{\text {wt }}$ PEs, we recovered the PEs at E12.5, E15.5 and E18.5 (Fig. 2A). At 12.5 days of gestation, the mean body weight of the $\mathrm{ng}^{\mathrm{H} 19 \Delta 13} / \mathrm{fg}^{\mathrm{wt}}$ PEs $(98 \pm 1.8 \mathrm{mg}, n=5)$ was $15 \%$ less than that of the controls derived from fertilized embryos (98 $\pm 1.8 \mathrm{mg}, n=5$ vs $115 \pm 1.2 \mathrm{mg}$, $n=5$ ), but the difference was not significant. However, the mean body weight gain of the $\mathrm{ng}^{\mathrm{H} 19 \Delta 13} / \mathrm{fg}^{\text {wt }}$ PEs was significantly greater than that of the $\mathrm{ng}^{\mathrm{wt}} / \mathrm{fg}^{\mathrm{wt}} \mathrm{PEs}$ $(77 \pm 3.0 \mathrm{mg}, n=5)$; this was $67 \%$ of the mean weight of the controls. It should be noted that thereafter the mean body weight of the $\mathrm{ng}^{\mathrm{H} 19 \Delta 13} / \mathrm{fg}^{\mathrm{wt}}$ PEs was definitely reduced from $74 \%(311 \pm 11.1 \mathrm{mg}, n=8)$, which was the mean weight of the controls at E15.5, to $55 \%$ $(726 \pm 15.5 \mathrm{mg}, n=7)$, which was the mean weight of the controls at E18.5 (Fig. 2B). These results showed that severe foetal growth retardation occurs mainly in the latter half of gestation. The cartilage and bone staining experiment revealed that the $\mathrm{ng}^{\mathrm{H} 19 \Delta 13} / \mathrm{fg}^{\text {wt }} \mathrm{PE}$ at E18.5 formed a delayed ossification pattern and had an abnormally shaped thoracic cage (Fig. 2C).

\section{Expression of the imprinted genes in $\mathrm{ng}^{\mathrm{H19 \Delta 13}} / \mathrm{fg}^{\mathrm{wt}} \mathrm{PE}$}

To gain a better understanding of the organ-specific gene expression, we carried out a quantitative expression analysis by real-time RT-PCR using major organs, i.e. the brain, tongue, heart, liver and leg (muscle and bone) at E12.5, E15.5 and E18.5 in controls and $\mathrm{ng}^{\mathrm{H} 19 \Delta 13} / \mathrm{fg}^{\mathrm{wt}}$ PEs. During the process of development, the expression levels of H19 and Igf2 were slightly reduced in the $\mathrm{ng}^{\mathrm{H} 19 \Delta 13} / \mathrm{fg}^{\mathrm{wt}} \mathrm{PEs}$ in most tissues as compared with the expression levels observed in the controls (Fig. 3A and B). H19 and Igf2 gene expressions were measured; the expression patterns obtained were similar to those of the controls (Fig. 3A and B) except for the low expression of the Igf2 in the liver. In all organs of the $\mathrm{ng}^{\mathrm{H} 19 \Delta 13} / \mathrm{fg}^{\mathrm{wt}} \mathrm{PEs}, \mathrm{Gt} / 2$ was overexpressed to approximately twice the control level, showing a peak at E15.5 (Fig. 3C). However, the Dlk1 expression was repressed in the above-mentioned five organs, with expression at levels below $20 \%$ of the controls (Fig. 3D). With regard to the tested organs, the expression levels of the paternally expressed Dio3 in the $\mathrm{ng}^{\mathrm{H} 19 \Delta 13} / \mathrm{fg}^{\mathrm{wt}} \mathrm{PEs}$ were approximately $70 \%$ of the controls, with the exception of the tongue $(<50 \%$; Fig. 3E), while the maternally expressed Mirg was overexpressed in most tissues of the $\mathrm{ng}^{\mathrm{H} 19 \Delta 13} / \mathrm{fg}^{\mathrm{wt}}$ PEs (Fig. 3F). The other paternally imprinted gene, namely, Rasgrf1 (de la Puente et al. 2002, Yoon et al. 2002), which is expressed from the paternal allele in the brain and stimulates growth hormone expression from the pituitary, was examined. The data showed that Rasgrf1 was completely repressed in the ng $^{\mathrm{H} 19 \Delta 13} /$ fg $^{\text {wt }}$ PEs (Fig. 3G).

We also carried out gene expression analysis in the survivor PEs in order to understand whether the expressions of the paternally imprinted genes were involved in the successful survival of the $\mathrm{ng}^{\mathrm{H} 19 \Delta 13} / \mathrm{fg}^{\mathrm{wt}} \mathrm{PE}$. The data clearly indicated that the expression of both paternally expressed DIk1 and Dio3 and maternally expressed Gt/2 and Mirg were corrected in the survivor PEs, suggesting that both sets of paternally imprinted genes are certainly involved in the extended development of the $\mathrm{ng}^{\mathrm{H} 19 \Delta 13} / \mathrm{fg}^{\mathrm{wt}}$ PE (Fig. 4).

\section{Methylation analysis of the IG-DMR of the DIk1-GtI2 domain}

The expressions of Dlk1, Gt/2, Dio3 and Mirg that are regulated by the methylation status of IG-DMR, located 

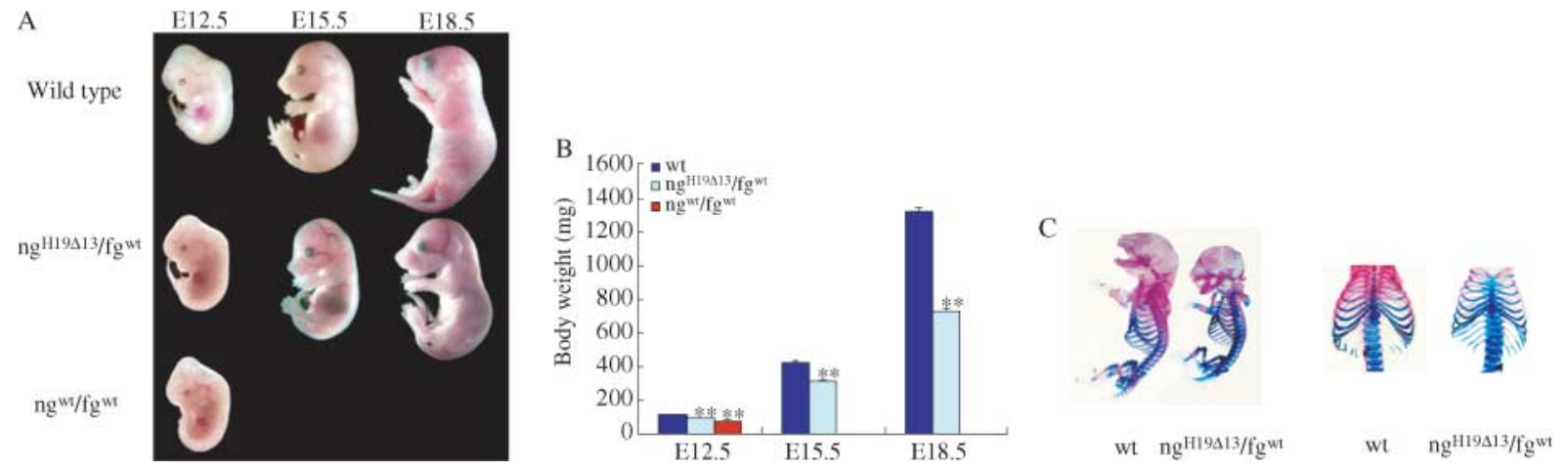

Figure 2 The prenatal growth of parthenogenetic $\mathrm{ng}^{\mathrm{H} 19 \Delta 13} / \mathrm{fg}^{\mathrm{wt}}$ embryos. (A) Live embryos of two genotypic parthenotes $-\mathrm{ng}^{\mathrm{wt}} / \mathrm{fg}^{\mathrm{wt}}$ and $\mathrm{ng}^{\mathrm{H} 19 \Delta 13} / \mathrm{fg}^{\mathrm{wt}}$ - were recovered at 12.5, 15.5 and 18.5 days of gestation. (B) The mean body weights of these parthenogenetic embryos were measured at E12.5, E15.5 and E18.5. The average body weight for each parthenogenetic embryo is shown, and data are expressed as means \pmS.E.M. E12.5 (controls: $n=5$; $\mathrm{ng}^{\mathrm{Wt}} / \mathrm{fg}^{\mathrm{wt}}: n=5 ; \mathrm{ng}^{\mathrm{H} 19 \Delta 13} / \mathrm{fg}^{\mathrm{wt}}: n=5$ ); E15.5 (controls: $n=10 ; \mathrm{ng}^{\mathrm{H} 19 \Delta 13} / \mathrm{fg}^{\mathrm{wt}}: n=8$ ); E18.5 (controls: $n=5$; $\left.\mathrm{ng}^{\mathrm{H} 19 \Delta 13} / \mathrm{fg}^{\mathrm{wt}}: n=7 ; * * P<0.01\right)$. (C) The cartilage and bone staining of the controls (wt) and $\mathrm{ng}^{\mathrm{H} 19 \Delta 13} / \mathrm{fg}^{\mathrm{wt}} \mathrm{PEs}$ at E18.5.

upstream of Gt/2, were normally expressed in the survivor $\mathrm{ng}^{\mathrm{H} 19 \Delta 13} / \mathrm{fg}^{\text {wt }} \mathrm{PEs}$; this perhaps resulted in normal birth. To gain further insight into the correction of the gene expressions, we analysed the methylation status of the IGDMR of the DIk1-Gt/2 domain. The analysis of the tail of Kaguya showed that the IG-DMR of the ng allele was completely methylated and that of the fg allele was also partially methylated (Fig. 5). Further, the intestine of another survivor $\mathrm{ng}^{\mathrm{H} 19 \Delta 13} / \mathrm{fg}^{\text {wt }} \mathrm{PE}$ at E19.5 PE also showed complete methylation of the IG-DMR in the ng allele. However, the IG-DMR was completely unmethylated in the tongue and the intestine in the growth-retarded $\mathrm{ng}^{\mathrm{H} 19 \Delta 13} / \mathrm{fg}^{\text {wt }}$ PE at E18.5 (Fig. 5). In the controls, the analysis of all tissues exhibited parental allele-specific methylation status with hypermethylated paternal allele and hypomethylated maternal allele. The results thus obtained gave an answer as to why Dlk1 was expressed only in Kaguya, revealing the importance of normal expression patterns of imprinted genes located in the Dlk1-Gt/2 domain in the normal development and survival of Kaguya (Kono et al. 2004). However, the reason for IG-DMR methylation remained unclear in only a few cases.

\section{Discussion}

In the present study, quantitative gene expression analysis of the two sets of co-ordinately regulated but oppositely expressed genes provided further insight into the characteristics of the $\mathrm{ng}^{\mathrm{H} 19 \Delta 13} / \mathrm{fg}^{\mathrm{wt}}$ PEs, which were able to develop to term. Using mutant mice we successfully regulated the imprinted expressions of both Igf2 and $\mathrm{H} 19$ in the $\mathrm{ng}^{\mathrm{H} 19 \Delta 13} / \mathrm{fg}^{\mathrm{wt}} \mathrm{PE}$, since the Igf2 and H19 genes are regulated by DMR located upstream of $\mathrm{H} 19$ sharing the same endoderm-derived tissue-specific enhancers located downstream of H19 (Feil et al. 1994, Sasaki et al. 1995, Thorvaldsen et al. 1998, Hark et al. 2000). In addition to being a major foetal growth regulator, lgf2 is a common regulator of haematopoietic stem cell differentiation (Zhang \& Lodish 2004). We also confirmed that the Igf2 expression was repressed in the $\mathrm{ng}^{\mathrm{wt}} / \mathrm{fg}^{\mathrm{wt}} \mathrm{PE}$ (data not shown) and, as expected, it recovered in the $\mathrm{ng}^{\mathrm{H} 19 \Delta 13} / \mathrm{fg}^{\mathrm{wt}}$ $\mathrm{PE}$. However, similar to the $\mathrm{ng}^{\mathrm{wt}} / \mathrm{fg}^{\mathrm{wt}} \mathrm{PE}$, the $\mathrm{ng}^{\mathrm{H} 19 \Delta 13} / \mathrm{fg}^{\mathrm{wt}}$ PE continued to exhibit growth retardation (Fig. 2) (Kono et al. 2004). The Igf1 and Igf2 genes are known to play important regulatory roles in foetal growth and development (Allan et al. 2001). The expression levels of lgf1, Igf1 $r$ and Igf2r in the two types of parthenotes at E12.5 did not differ from those of the controls (data not shown). These findings suggest that additional factors may be involved in the growth of the two types of parthenotes. Although $\mathrm{H} 19$ encodes an untranslated maternal RNA, the correct imprinted expression of the gene in various tissues may be involved in foetal development (Kono et al. 2002) and tumorigenesis (Juan et al. 2000, Lottin et al. 2002). In the present study, H19 expression increased with gestation in most tissues, except the brain and heart, and the highest expression of Igf2 was observed at E15.5, after which the levels decreased, although a developmental increase was observed in certain important tissues (Fig. 3).

Paternally imprinted Dlk1 and Gt/2 are also important with regard to foetal lethality and growth retardation in maternal disomic mice (Georgiades et al. 2000, Schmidt et al. 2000, Lin et al. 2003). They are another set of co-ordinately regulated but oppositely expressed genes, located on the distal region of chromosome 12. In the present study, we observed the increased expression of Dlk1 in the controls at E15.5, while the gene expression was repressed in all parthenotes, which showed retardation throughout development and were estimated to be unable to survive beyond E19.5 (Figs 3 and 4). The repression of Dlk1 is thought to be a major reason for developmental failure in the $\mathrm{ng}^{\mathrm{H} 19 \Delta 13} / \mathrm{fg}^{\mathrm{wt}} \mathrm{PE}$, since the paternally expressed Dlk1 encodes a cell-surface transmembrane protein and is essential for normal development (Moon et al. 2002), haematopoiesis (Doggett et al. 2002, La 
A

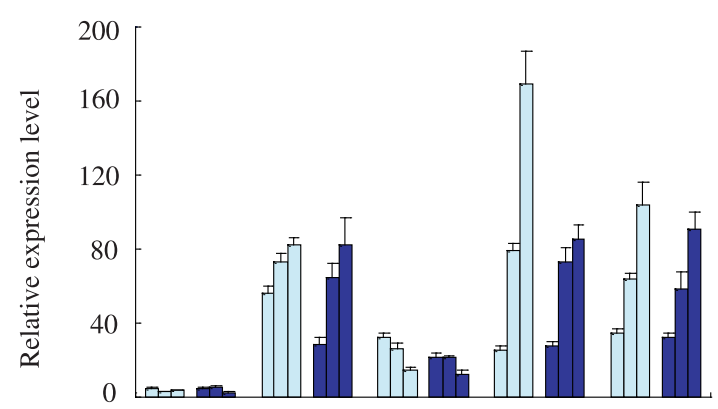

C

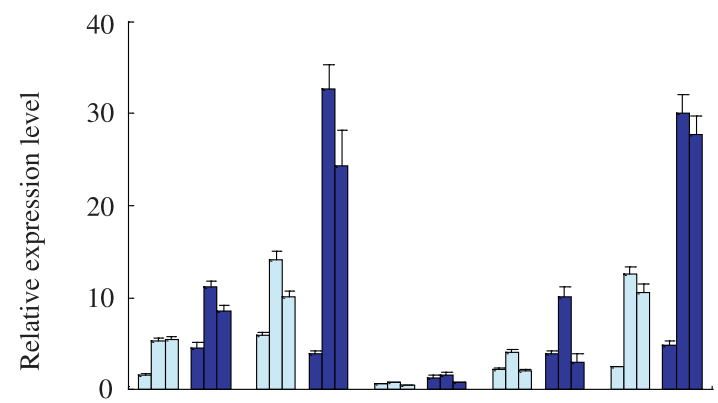

$\mathbf{E}$

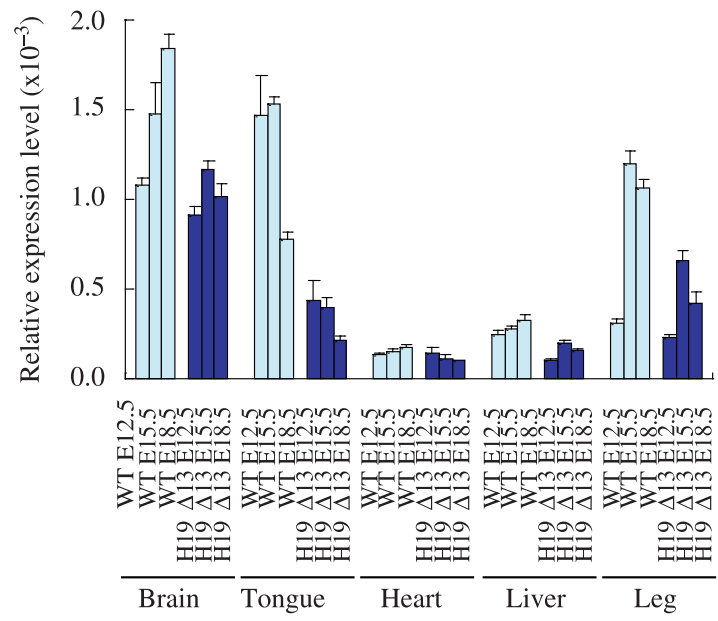

G

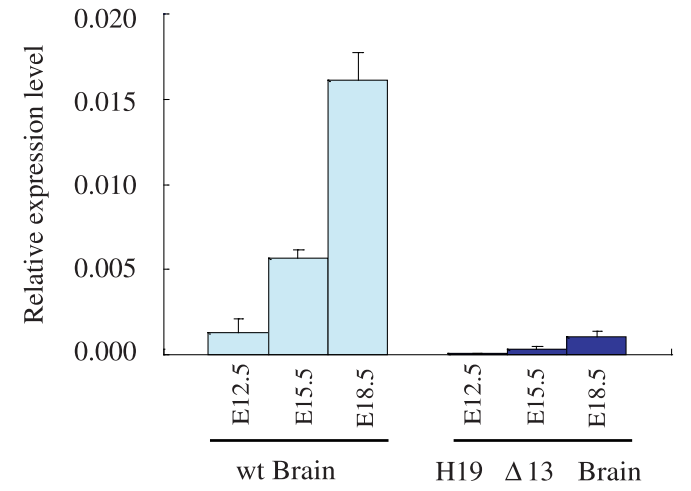

B

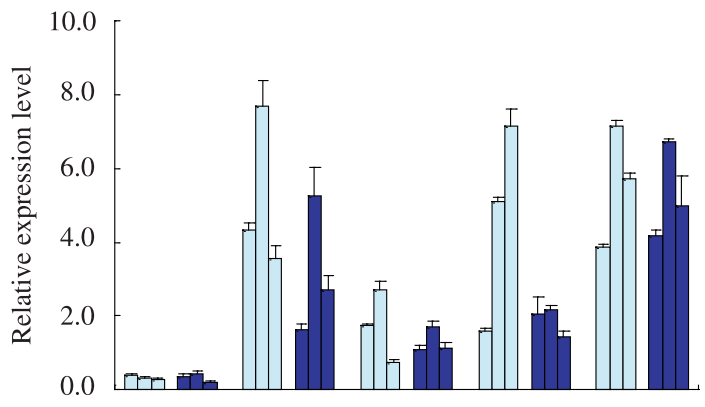

D

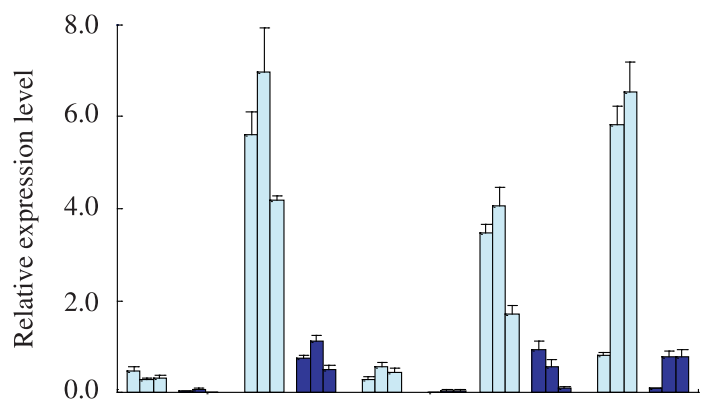

F

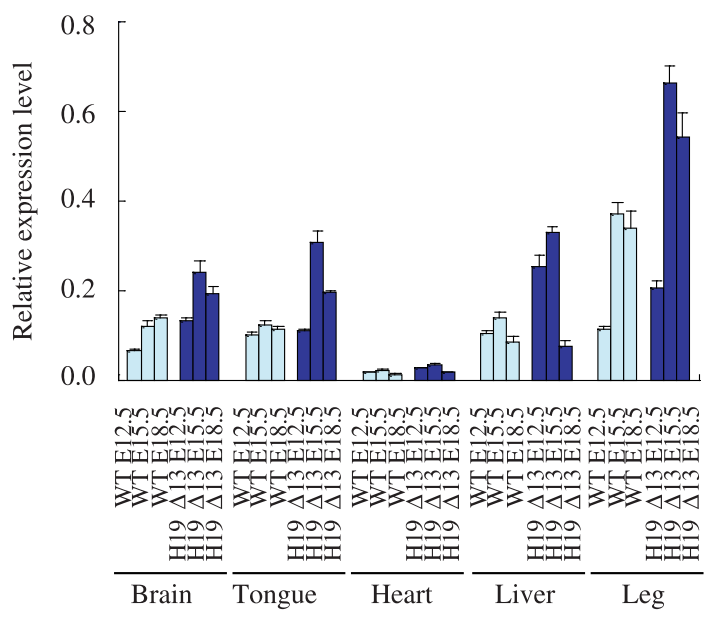

Figure 3 Quantitative analysis of the expression of imprinted genes in five types of tissues at 12.5, 15.5 and 18.5 days of gestation of $\mathrm{ng}^{\mathrm{H} 19 \Delta 13} / \mathrm{fg}^{\mathrm{wt}} \mathrm{PEs}$. Total RNA was extracted from each tissue sample at 12.5, 15.5 and 18.5 days of gestation of the $\mathrm{ng}^{\mathrm{H} 19 \Delta 13} / \mathrm{fg}^{\mathrm{Wt}} \mathrm{PE}$ and from the controls (wt). The cDNAs were synthesized using a SuperScript II RnaseH reverse transcriptase kit in a reaction solution (20 $\mu$ l) containing the total RNA $(1 \mu \mathrm{g})$ prepared from each tissue. The expression levels of the seven imprinted genes - (A) H19, (B) lgf2, (C) Gt/2, (D) DIk1, (E) Dio3, (F) Mirg and (G) Rasgrf1 - were analyzed quantitatively using real-time RT-PCR. The expression of each gene is shown as the average of the expression levels relative to that of Gapdh, which was used as an internal control. Data are expressed as means \pm S.E.M. $(n=5)$. 
A

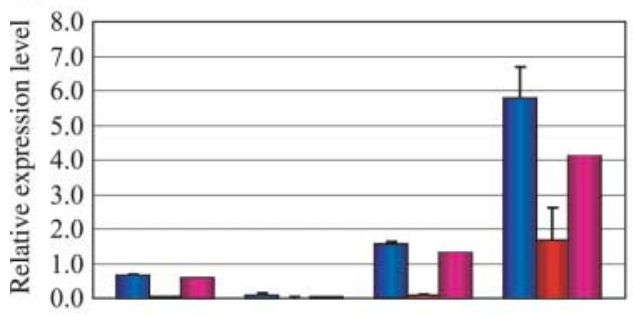

C

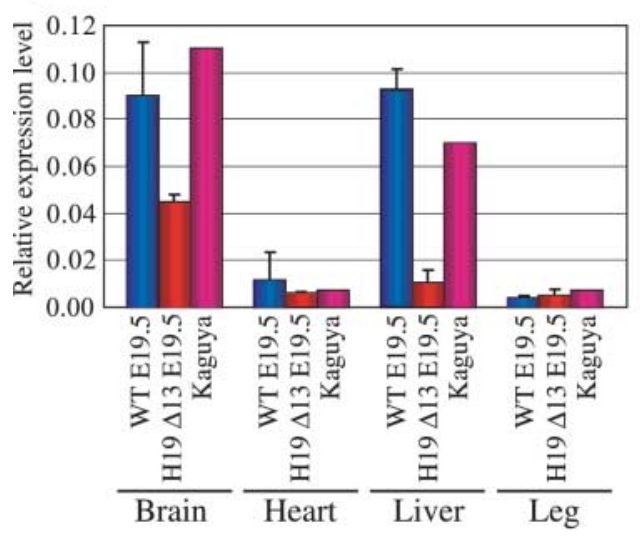

B

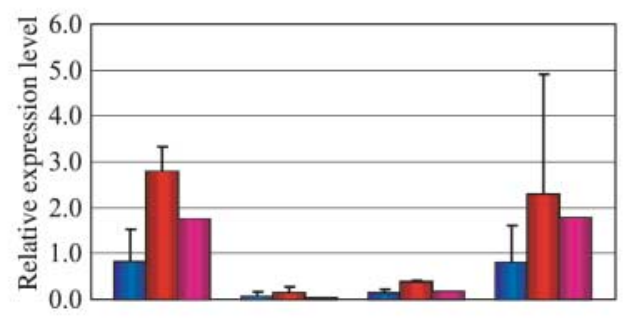

D

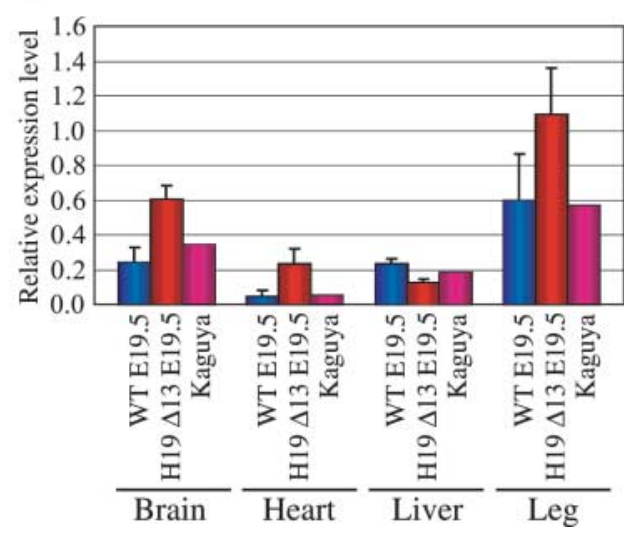

Figure 4 Quantitative analysis of the expression of paternally imprinted genes at 19.5 days of gestation of $\mathrm{ng}^{\mathrm{H} 19 \Delta 13} / \mathrm{fg}^{\mathrm{wt}}$ PEs and $\mathrm{ng}^{\mathrm{H} 19 \Delta 13} / \mathrm{fg}^{\text {wt }}$ survivors. The expression of four imprinted genes - (A) Dlk1, (B) Gt/2, (C) Dio3 and (D) Mirg - at E19.5 of the $n^{\mathrm{H} 19 \Delta 13} / \mathrm{fg}^{\mathrm{wt}} \mathrm{PE}(n=3)$, $\mathrm{ng}^{\mathrm{H} 19 \Delta 13} / \mathrm{fg}^{\text {wt }}$ survivor $(n=1)$ and controls $(n=3)$ were analysed by quantitative real-time PCR. The expression of each gene is shown as the average of the expression levels relative to Gapdh. Data are expressed as means \pm S.E.M.
Motte-Mohs et al. 2005, Li et al. 2005) and ossification (Moon et al. 2002). The maternally expressed Gt/2 encodes an untranslated RNA and is enhanced in the $\mathrm{ng}^{\mathrm{H} 19 \Delta 13} / \mathrm{fg}^{\mathrm{wt}} \mathrm{PE}$ (Figs 3 and 4); however, normal expression of Gt/2 was observed in some important tissues of other survivor with an apparently normal phenotype at birth (Fig. 4) (Kono et al. 2004). These results suggest that the correct expressions of DIk1 and Gt/2 also play important roles in the development and survival of the ng/fg PE. Moreover, the increased expression of the maternally expressed Mirg and the decreased expression of the paternally expressed Dio3 were also invested in the

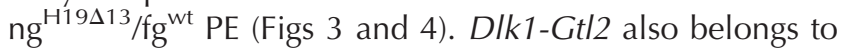
members of the $1-\mathrm{Mb}$ imprinted cluster, which is located on mouse distal chromosome 12 (Lin et al. 2003). The phenotype of the $\mathrm{ng}^{\mathrm{H} 19 \Delta 13} / \mathrm{fg}^{\mathrm{wt}}$ PE resembled that of the mice with $M U P D$ for chromosome 12 (Georgiades et al. 2000) rather than that of the DIk1 null mice (Moon et al. 2002). However, there is no evidence for the involvement of Dio3, Mirg, etc. in foetal development.

The present results, together with the results of our previous study (Kono et al. 2004), demonstrated that the normal level of paternally expressed DIk1 was invested in Kaguya, which survived and grew up to adulthood with normal reproductive ability. We carried out further methylation analysis of the IG-DMR of DIk1-Gt/2. Interestingly, we observed a higher frequency of hypermethylated patterns in the $\mathrm{ng}^{\mathrm{H} 19 \Delta 13}$ allele and partial methylation in the fg allele (Fig. 5). In contrast, the DMR of the $\mathrm{ng}^{\mathrm{H} 19 \Delta 13} / \mathrm{fg}^{\mathrm{wt}}$ $\mathrm{PE}$ with growth retardation was completely hypomethylated. The reason for the different IG-DMR methylation patterns of Dlk1 in survivor ng ${ }^{\mathrm{H} 19 \Delta 13} / \mathrm{fg}^{\text {wt }}$ PEs is unknown. However, the data on both methylated ng and $\mathrm{fg}$ alleles suggests that the unexpected methylation of DMR could occur after oocyte reconstruction, but not during oogenesis. These results indicate that the normal expression of DIk1 together with the neighbouring imprinted genes is an important factor in the normal development and survival of $\mathrm{ng}^{\mathrm{H} 19 \Delta 13} / \mathrm{fg}^{\text {wt }}$ PEs.

The present study demonstrated that the expression of the paternally imprinted genes regulates foetal growth after mid gestation; its inappropriate expression leads to foetal growth retardation and lethality in the $\mathrm{ng}^{\mathrm{H} 19 \Delta 13} / \mathrm{fg}^{\mathrm{wt}} \mathrm{PE}$. Therefore, both paternally and maternally expressed genes act as a barrier to parthenogenesis in mammals. Together with the results of our previous studies, the present findings support the idea that adequate correction of the expression dosage of the imprinted genes (Igf2-H19 and DIk1-Gt/2) by gene manipulation may promote long-term normal development in the $\mathrm{ng}^{\mathrm{H} 19 \Delta 13} / \mathrm{fg}^{\text {wt }}$ PE in mice.

\section{Acknowledgements}

We thank Dr Shirley Tilghman, Princeton University, for the gift of mutant mice, and Anne Ferguson-Smith for discussion of this work. This study was supported by a grant from the Bio-oriented Technology Research Advancement Institution (BRAIN), Japan. The authors declare that there is no conflict of interest that would prejudice the impartiality of this scientific work 


\section{References}

Allan GJ, Flint DJ \& Patel K 2001 Insulin-like growth factor axis during embryonic development. Reproduction 122 31-39.

Doggett KL, Briggs JA, Linton MF, Fazio S, Head DR, Xie J, Hashimoto Y, Laborda J \& Briggs RC 2002 Retroviral mediated expression of the human myeloid nuclear antigen in a null cell line upregulates Dlk1 expression. Journal of Cellular Biochemistry 86 56-66.

Feil R, Walter J, Allen ND \& Reik W 1994 Developmental control of allelic methylation in the imprinted mouse Igf2 and H19 genes. Development $1202933-2943$.

Georgiades P, Watkins M, Surani MA \& Ferguson-Smith AC 2000 Parental origin-specific developmental defects in mice with uniparental disomy for chromosome 12. Development 127 4719-4728.

Hark AT, Schoenherr CJ, Katz DJ, Ingram RS, Levorse JM \& Tilghman SM 2000 CTCF mediates methylation-sensitive enhancerblocking activity at the H19/lgf2 locus. Nature 405 486-489.

Juan V, Crain C \& Wilson C 2000 Evidence for evolutionarily conserved secondary structure in the H19 tumor suppressor RNA. Nucleic Acids Research 28 1221-1227.

Kobayashi S, Wagatsuma $H$, Ono R, Ichikawa $H$, Yamazaki $M$, Tashiro H, Aisaka K, Miyoshi N, Kohda T, Ogura A, Ohki M, Kaneko-Ishino T \& Ishino F 2000 Mouse Peg9/Dlk1 and human PEG9/DLK1 are paternally expressed imprinted genes closely located to the maternally expressed imprinted genes: mouse Meg3/Gtl2 and human MEG3. Genes to Cells 5 1029-1037.

Kono T, Obata Y, Yoshimzu T, Nakahara T \& Carroll J 1996 Epigenetic modifications during oocyte growth correlates with extended parthenogenetic development in the mouse. Nature Genetics 13 91-94.

Kono T, Sotomaru Y, Katsuzawa Y \& Dandolo L 2002 Mouse parthenogenetic embryos with monoallelic H19 expression can develop to day 17.5 of gestation. Developmental Biology 243 294-300.

Kono T, Obata Y, Wu Q, Niwa K, Ono Y, Yamamoto Y, Park E, Seo J \& Ogawa H 2004 Birth of parthenogenetic mice that can develop to adulthood. Nature 428 860-864.

La Motte-Mohs RN, Herer E \& Zuniga-Pflucker JC 2005 Induction of T-cell development from human cord blood hematopoietic stem cells by Delta-like 1 in vitro. Blood 105 1431-1439.

Leighton PA, Ingram RS, Eggenschwiler J, Efstratiadis A \& Tilghman SM 1995 Disruption of imprinting caused by deletion of the $\mathrm{H} 19$ gene region in mice. Nature 375 34-39.

Li L, Forman SJ \& Bhatia R 2005 Expression of DLK1 in hematopoietic cells results in inhibition of differentiation and proliferation. Oncogene 24 4472-4476.

Lin SP, Youngson N, Takada S, Seitz H, Reik W, Paulsen M, Cavaille J \& Ferguson-Smith AC 2003 Asymmetric regulation of imprinting on the maternal and paternal chromosomes at the Dlk1-Gt/2 imprinted cluster on mouse chromosome 12. Nature Genetics 35 97-102.
Lottin S, Vercoutter-Edouart AS, Adriaenssens E, Czeszak X, Lemoine J, Roudbaraki M, Coll J, Hondermarck H, Dugimont T \& Curgy JJ 2002 Thioredoxin post-transcriptional regulation by $\mathrm{H} 19$ provides a new function to mRNA-like non-coding RNA. Oncogene 21 $1625-1631$.

Moon YS, Smas CM, Lee K, Villena JA, Kim KH, Yun EJ \& Sul HS 2002 Mice lacking paternally expressed Pref-1/Dlk1 display growth retardation and accelerated adiposity. Molecular and Cellular Biology 22 $5585-5592$.

Obata Y \& Kono T 2002 Maternal primary imprinting is established at a specific time for each gene throughout oocyte growth. Journal of Biological Chemistry 277 5285-5289.

de la Puente A, Hall J, Wu YZ, Leone G, Peters J, Yoon BJ, Soloway P \& Plass C 2002 Structural characterization of Rasgrf1 and a novel linked imprinted locus. Gene $291287-297$.

Sasaki H, Ferguson-Smith AC, Shum AS, Barton SC \& Surani MA 1995 Temporal and spatial regulation of H19 imprinting in normal and uniparental mouse embryos. Development 121 4195-4202.

Schmidt JV, Matteson PG, Jones BK, Guan XJ \& Tilghman S 2000 The Dlk1 and Gtl2 genes are linked and reciprocally imprinted. Genes and Development 15 1997-2002.

Surani MA \& Barton SC 1983 Development of gynogenetic eggs in the mouse: implications for parthenogenetic embryos. Science 222 1034-1036.

Takada S, Paulsen M, Tevendale M, Tsai CE, Kelsey G, Cattanach BM \& Ferguson-Smith AC 2002 Epigenetic analysis of the Dlk1-Gtl2 imprinted domain on mouse chromosome 12: implications for imprinting control from comparison with Igf2-H19. Human Molecular Genetics 11 77-86.

Thorvaldsen JL, Duran KL \& Bartolomei MS 1998 Deletion of the H19 differentially methylated domain results in loss of imprinted expression of H19 and Igf2. Genes and Development 12 3693-3702.

Whittingham D 1971 Culture of mouse ova. Journal of Reproduction and Fertility Supplement 14 7-21.

Yoon BJ, Herman H, Sikora A, Smith LT, Plass C \& Soloway PD 2002 Regulation of DNA methylation of Rasgrf1. Nature Genetics 30 92-96.

Zhang CC \& Lodish HF 2004 Insulin-like growth factor 2 expressed in a novel fetal liver cell population is a growth factor for hematopoietic stem cells. Blood $1032513-2521$.

Received 17 August 2005

First decision 13 September 2005

Revised manuscript received 2 November 2005

Accepted 17 November 2005 